\title{
Spring food habits of Wolverine (Gulo gulo) in the Colville River watershed, Alaska
}

\author{
Ross R. Dorendorf ${ }^{1, ~ *, ~ K e l l y ~ J . ~ S i v y ~}{ }^{2}$, Martin D. Robards ${ }^{1}$, Tom W. Glass ${ }^{1}$, and Kristine L. \\ PilgRiM $^{3}$
}

${ }^{1}$ Wildlife Conservation Society, Arctic Beringia Program, 3550 Airport Way, Suite 5, Fairbanks, Alaska 99709 USA

${ }^{2} 3820$ Ullrbahn Road \#B, Fairbanks, Alaska 99709 USA

${ }^{3}$ Rocky Mountain Research Station, National Genomics Center for Wildlife and Fish Conservation, 800 East Beckwith Avenue, Missoula, Montana 59801 USA

${ }^{*}$ Corresponding author: rdore308@gmail.com

Dorendorf, R.R., K.J. Sivy, M.D. Robards, T.W. Glass, and K.L. Pilgrim. 2018. Spring food habits of Wolverine (Gulo gulo) in the Colville River watershed, Alaska. Canadian Field-Naturalist 132(3): 268-278. https://doi.org/10.22621/cfn.v132 i3.1947

\begin{abstract}
Wolverines (Gulo gulo) are relatively abundant on the North Slope of Alaska, an Arctic ecosystem dominated by tundra habitats that run north from the Brooks Range across a wide coastal plain to the Beaufort Sea. The region contains a range of potential Wolverine prey species, including ungulates (Caribou [Rangifer tarandus], Moose [Alces americanus]), Arctic Ground Squirrel (Urocitellus parryii), and both Soricidae and Cricetidae species. The seasonal composition of these, and other prey species, in the Wolverines' diet is not well understood. We collected Wolverine scats during spring (March-May) on the North Slope while tracking animals from snowmobiles and with helicopters that visited areas identified as of interest during ground surveys or using global positioning system collared animals. We analyzed prey remains in 48 scat samples based on hair, bone, and other prey fragments. We then calculated frequency of occurrence, percentage of occurrence, and weighted percent volume for each major prey category detected. We confirmed species identity of scats as Wolverine by amplifying the control region of the mitochondrial DNA. We estimated spring diet diversity and richness based on nine major prey categories detected in scats. Ungulates and cricetids together constituted $69 \%$ of the Wolverines' spring diet, with Snowshoe Hare (Lepus americanus) constituting $9 \%$, fox (Vulpes spp.) 6\%, Arctic Ground Squirrel 2\%, birds 2\%, American Beaver (Castor canadensis) less than 1\%, and unknown 6\%.
\end{abstract}

Key words: Wolverine; Gulo gulo; diet; food habits; frequency of occurrence; percentage of occurrence; volume of occurrence; diet richness; diet diversity; Alaska

\section{Introduction}

Wolverines (Gulo gulo) are known as "facultative scavengers" that alternate between hunting live prey, scavenging, and consuming previously cached food to fulfill their energy requirements (Magoun 1987; Banci 1994; Dijk et al. 2008; Dalerum et al. 2009; Koskela et al. 2013; Mattisson 2016). In the Arctic, Wolverines generally switch from killing and consuming cached ungulate carrion (e.g., Caribou [Rangifer tarandus]) in the winter, to hunting small mammals (e.g., Arctic Ground Squirrel [Urocitellus parryii]) during the summer (Magoun 1987; Dijk et al. 2008). Because habitat and prey species availability differ across the Arctic and across seasons, Wolverines likely adjust their diet according to available prey sources (Churchill 1955; MacDonald and Cook 2009; Lenart 2015). Variation of diet composition may reflect prey availability, which in turn may influence the distribution and abundance of Wolverines. In this study, we focus on spring diet composition during the transition from winter to summer, defined here as March through May, in the Colville River watershed of the Alaskan Arctic.

Across their range, Wolverines feed on a variety of prey species comprised primarily of ungulates (Moose [Alces americanus], Caribou) in North America and Europe (Landa et al. 1997; Dalerum et al. 2009; Koske- la et al. 2013; Inman and Packila 2015). However, Wolverines also forage on small mammals, birds, and fish (Magoun 1987; Landa et al. 1997; Samelius et al. 2002; Shardlow 2013; Inman and Packila 2015). In the North American Arctic, in addition to ungulates, Wolverines feed on ptarmigan (Lagopus spp.), soricids (shrews), cricetids (voles, lemmings, mice), hare (Lepus spp.), and Arctic Ground Squirrels (Banci 1987; Mulders 2001). One study conducted on Alaska's North Slope investigated the Wolverines' seasonal diet composition in summer (May-August) and winter (September-April) near the Utukok River in the foothills of the Brooks Range, and found that Wolverines relied heavily on Arctic Ground Squirrel almost the entire year, except in midwinter (December-February) when their diet shifted to Caribou (Magoun 1987). Caribou undertake seasonal migrations and Moose reside at low densities on the North Slope of Alaska (Fancy et al. 1989; Carroll 2014; Tape et al. 2016), suggesting that Wolverines may need to rely on cached food or alternative prey sources when ungulates are scarce.

Information on the relative contribution of small prey such as cricetids, soricids, Snowshoe Hare (Lepus americanus), ptarmigan, and large prey in the Wolverines' diet across the Alaskan Arctic is lacking, but could contribute towards understanding how prey selection influen-

A contribution towards the cost of this publication has been provided by the Thomas Manning Memorial Fund of the Ottawa Field-Naturalists' Club. 
ces Wolverine survival and reproductive success (Krebs et al. 2004; Persson 2005; Koskela et al. 2013). A lack of large ungulate prey coupled with dwindling food caches during early spring may force Wolverines to switch from ungulate carrion to other prey sources (Persson 2005). Investigating the relative presence of large versus small mammals (Cricetidae, Soricidae, Sciuridae, Leporidae) in the Wolverines' spring diet is an important step in understanding how Wolverines in the Arctic address a period of high energetic demands (Magoun 1987; Landa et al. 1997; Dalerum et al. 2009).

We collected Wolverine scats on the North Slope near Umiat, Alaska to determine spring diet composition of Wolverines in the foothills of the Brooks Range and Beaufort coastal plain (Figure 1). Our objectives were to describe the spring diet composition of Wolverines in our study area and compare the portion of that period's diet made up of small mammals versus ungulate prey.

\section{Study Area}

Our study took place in 2016 within $120 \mathrm{~km}$ of Umiat, Alaska in the National Petroleum Reserve-Alaska (NPR-A; Figure 1). On the southeast border of the NPR-A lies the Colville River corridor made up of flood plain with shrubs such as alder (Alnus spp. Miller) and willow (Salix spp. L.). Northwest of the Colville River are rolling hills with steep cut drainages, composed of upland tundra vegetation such as Tussock Cottongrass (Eriophorum vaginatum L.) and mountain avens (Dryas spp. L.; Viereck et al. 1992). Further north, the land transitions from rolling hills to a flattened terrain filled with lakes and ponds, which extends north to the coast of the Beaufort Sea. This area is considered lowland tundra, containing Water Sedge (Carex aquatillis Wahlenberg) and other mesic plant species (Churchill 1955). At Umiat, average temperatures range from $-30^{\circ} \mathrm{C}$ in February to $13^{\circ} \mathrm{C}$ in July (NOAA 2018). Average annual rain and snow accumulation are $13.9 \mathrm{~cm}$ and $84.3 \mathrm{~cm}$, respectively.

While large ungulates, cricetids, soricids, other small mammals (e.g., Snowshoe Hare, Arctic Ground Squirrel), and birds are available as prey to Wolverines during spring (Table 1), their relative abundance may change over time and space (MacDonald and Cook 2009). Caribou are seasonally available as they migrate through the study area in spring and fall, residing near the coast in summer, and in the Brooks Range to the south in winter (Lenart 2015). Moose and Muskox (Ovi-

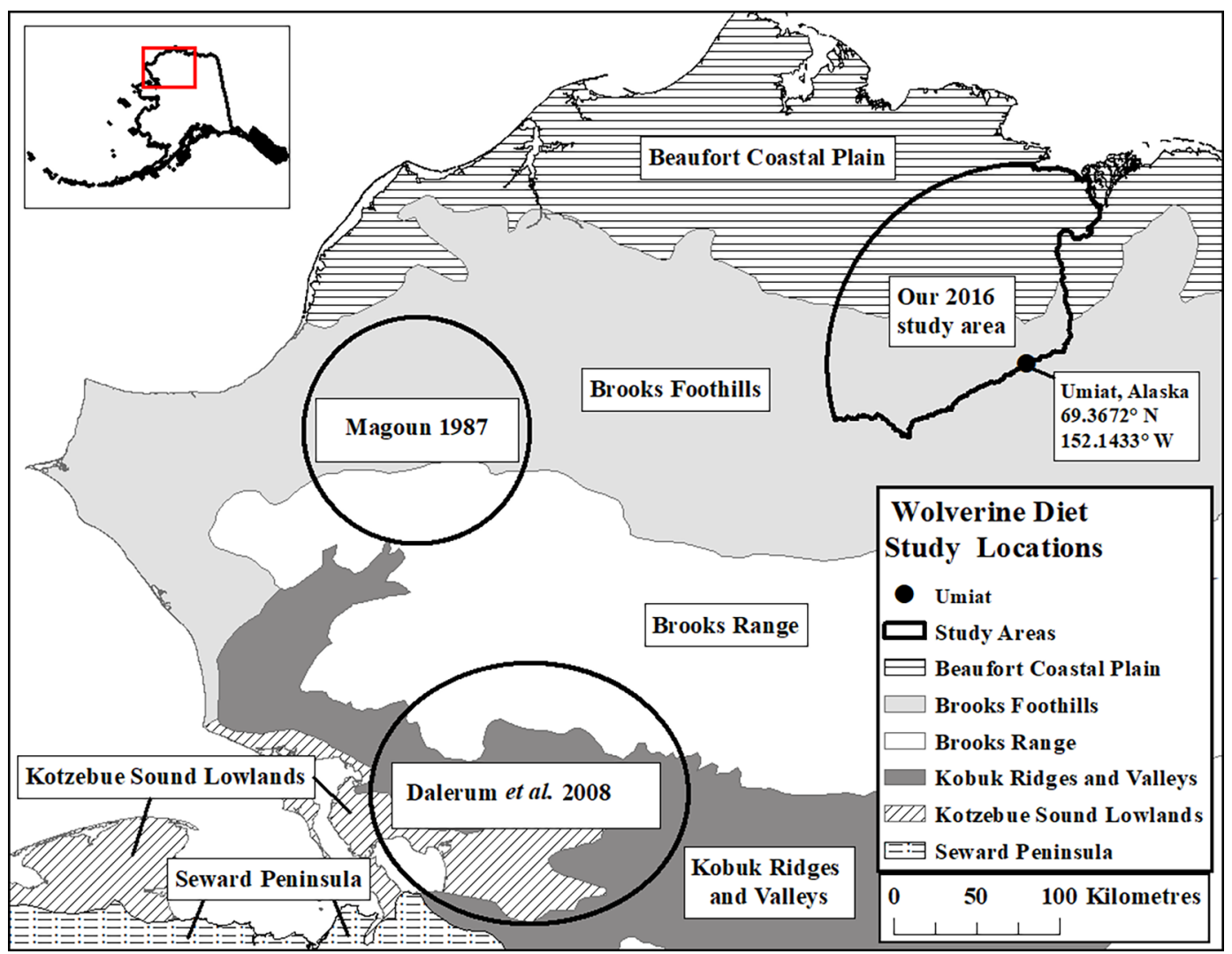

FIGURE 1. Wolverine (Gulo gulo) diet study areas compared to the ecoregions of northern Alaska, USA. Our 2016 study area took place within $120 \mathrm{~km}$ of Umiat, Alaska in the National Petroleum Reserve-Alaska. 
bos moschatus) persist at low densities year-round, but Muskox only inhabit the northern portion of the study area near the Beaufort Sea (MacDonald and Cook 2009; Carroll 2014). Smaller prey that inhabit the study area year-round include: cricetids, soricids, Arctic Ground Squirrel, Snowshoe Hare, Willow Ptarmigan (Lagopus lagopus), and Rock Ptarmigan (L. muta; MacDonald and Cook 2009). Cricetids and soricids are active underneath the snow year-round, while Arctic Ground Squirrels hibernate, reducing the Wolverines access to these species in winter and early spring (Batzli and Sobaski 1980). In contrast, Snowshoe Hare and ptarmigan are available year-round. Wolverines are known to cache their prey, thus any species listed above may be consumed during winter and spring (Magoun 1987).

\section{Methods}

Scat collection

We followed Wolverine tracks by snowmobile 10 March-29 April 2016 to collect scats for diet analysis. We followed tracks opportunistically while maintaining a live-capture trap line, picking up scats from unknown individuals. When we encountered relatively fresh Wolverine tracks (e.g., not blown over, or covered with snow), we followed the track against the direction of travel to avoid harassing the animal. If tracks were older (e.g., blown over with snow) we followed the track in either direction. We stopped tracking when the animal travelled through terrain unnavigable by snowmobile, or when tracking conditions deteriorated. We recorded global positioning system (GPS) coordinates for each scat collected. We recorded the location of Wolverine snow-holes encountered while tracking and returned to collect scats in late spring after the snow melted. At carcass sites, we collected all scats, but only included one randomly selected scat in our analysis to avoid pseudoreplication and the over-representation of the prey species at the carcass site (Marucco et al. 2008; Bacon et al. 2011).

We captured five Wolverines 6-26 April 2016 and affixed GPS collars (Tellus light model, Followit Sweden AB, Lindesberg, Sweden) programmed to record locations every 20 minutes. We captured three females including one juvenile and two reproductive females (with kits), one juvenile, and an adult male. Collars remained on animals until mid-summer when drop-off mechanisms were activated. In addition to scats collected while tracking unknown individuals, we collected scats from areas where collard Wolverines spent $>20$ minutes in an area $<100 \mathrm{~m}^{2}$, signifying an extended stay in a localized area where scat could be found (called a cluster). We returned to snow-holes and clusters on 29 May to collect scats.

We placed scats in Whirl-Packs ${ }^{\circledR}$ (Nasco, Fort Atkinson, Wisconsin, USA) and stored them at temperatures ranging from $4^{\circ} \mathrm{C}$ to $-35^{\circ} \mathrm{C}$ while in the field $(10$ March -29 April, and 29 May). After leaving the field, we stored samples in $\mathrm{a}-20^{\circ} \mathrm{C}$ freezer for a maximum of 1.5 months.

We radio-tracked collared Wolverines with fixedwinged aircraft 13-22 May to observe feeding behaviour. We watched for visually identifiable prey (e.g., a

TABLE 1. List of potential prey items available in late winter and early spring to Wolverines within the National Petroleum Reserve-Alaska (MacDonald and Cook 2009).

\begin{tabular}{lll}
\hline \hline Family & Common name & Scientific name \\
\hline Bovidae & Muskox & Ovibos moschatus \\
Canidae & Gray Wolf & Canis lupus \\
& Arctic Fox & Vulpes lagopus \\
Cervidae & Red Fox & Vulpes vulpes \\
& Moose & Alces americanus \\
Cricetidae & Caribou & Rangifer tarandus \\
& Peary Land Collard Lemming & Dicrostonyx groenlandicus \\
& Brown Lemming & Lemmus trimucronatus \\
& Singing Vole & Microtus miurus \\
Felidae & Tundra Vole & Microtus oeconomus \\
Leporidae & Northern Red-backed Vole & Myodes rutilus \\
Mustelidae & Lynx & Lynx canadensis \\
& Snowshoe Hare & Lepus americanus \\
Phasianidae & Wolverine & Gulo gulo \\
& Ermine & Mustela erminea \\
Sciuridae & Least Weasel & Mustela nivalis \\
Soricidae & Willow Ptarmigan & Lagopus lagopus \\
& Rock Ptarmigan & Lagopus muta \\
& Arctic Ground Squirrel & Urocitellus parryii \\
Ursidae & Cinereus Shrew & Sorex cinereus \\
& Tundra Shrew & Sorex tundrensis \\
\hline \hline & Barren Ground Shrew & Sorex ugyunak \\
& Holarctic Least Shrew & Sorex minutissimus \\
& Brown Bear & Ursus arctos \\
& Polar Bear & Ursus maritimus \\
\hline
\end{tabular}


Moose carcass), and observed hunting behaviour (e.g., hunting small prey). We recorded time, location, collared animal's identity, and observed prey or behaviour.

\section{Scat analysis}

We confirmed identification of each scat as Wolverine with faecal DNA analysis, because tracking trails and clusters also had sign of other predators (e.g., foxes). We used three methods to sample faecal DNA from each scat. First, we scraped each scat using two flat-sided toothpicks and placed each into a coin envelope. Second, we removed $1 \mathrm{~mL}$ of faecal material from each scat and placed it into a vial. Finally, we swabbed each scat with a sterile cotton-tipped swab and placed it into a separate vial. We sent all samples to the Rocky Mountain Research Station, National Genomics Centre for Wildlife and Fish Conservation in Missoula, Montana to verify the species identity. We used the QIAGEN QIAamp Fast DNA Stool Mini Kit (QIAGEN Inc., Valencia, California, USA) following the manufacturer's instructions for DNA extraction. We amplified the control region of mitochondrial DNA (mtDNA) for species identification following Schwartz et al.'s (2007) methods for processing samples.

Following DNA sampling, we transferred individual scats into nylon mesh stockings and washed them on gentle cycle in a Haier HLP23E compact washing machine (Haier Appliances, Rapid City, South Dakota, USA). We washed scats for 2-3 cycles until the water ran clear (indicating the removal of the faecal matrix material) and air-dried samples for $48 \mathrm{~h}$. We weighed each scat and identified prey remains by comparing microscopic qualities of medulla, cortex, and cuticular scale patterns of mammalian hairs to published keys (Moore et al. 1974; Carlee and Horelick 2011), and by comparing hair, teeth, claw, and bone fragments to reference specimens on loan from University of Alaska Museum of the North, Fairbanks, Alaska. We identified prey remains to species level or nearest taxonomic grouping if remains were highly degraded. We visually estimated the proportion of each prey type present in each scat, rounded to the nearest $5 \%$. We also sub-sampled scats after determining the proportion of the scat belonging to each prey category. Of the scats that contained suspected cricetids and soricids, we collected 15-30 hairs to determine species identification through DNA analysis.

We used methods from Dijk et al. (2007) and the recommendations of Klare et al. (2011) to characterize Wolverine diet. Frequency of occurrence (FO) was calculated from the binary occurrence of each prey item in each scat, and represents the percentage of the total sample size containing each prey item:

$$
F O_{i}(\%)=\frac{n_{i}}{N} \times 100
$$

where $n_{i}$ is the number of scats containing species $i$ and $\mathrm{N}$ represents the total number of scats (Ciucci et al. 1996).
Percentage of occurrence (PO) is calculated from binary occurrence data that represents the percentage of the total prey occurrences containing each prey item:

$$
P O_{i}(\%)=\frac{n_{i}}{\sum n_{i}} \times 100
$$

where $n_{i}$ is the number of scats containing species $i$. Finally, we calculated weighted volume (VOL) to determine the relative importance of prey in the diet in the absence of a biomass calibration (Klare et al. 2011).

Weighted volume is the sum of percent volume of each prey item in scats, divided by the total number of scats:

$$
V O L_{i}(\%)=\frac{\sum v_{i}}{N} \times 100
$$

where $v_{i}$ is the proportion of each scat containing species $i$.

Scats collected while tracking individual Wolverines were treated as individual sample units. Scats collected from individual snow-holes and clusters were combined and treated as a single sample unit, because the large piles of scats collected at clusters, deposited by an unknown number of individuals, made it difficult to differentiate among individual scat samples. For scats collected at clusters, $v_{i}$ was equal to the proportion of the total scat volume at a cluster.

Weighted volume was calculated for each prey item detected in scats. We then grouped prey items into one of nine major prey categories and calculated weighted volume of each major prey category in scats. The nine prey categories were: ungulate, Snowshoe Hare, Arctic Ground Squirrel, cricetids and soricids, birds (Aves), fox, American Beaver, unknown (including any unidentifiable remains), and other (consisting of vegetation, gravel, and woody debris). Items in the "other" category were expected to be incidentally ingested as a result of digging up food caches or excavating small mammal burrows. Although Wolverines have been documented to consume vegetation and berries, we assumed vegetation was incidentally ingested while feeding (Lofroth et al. 2007) or picked up during collection of scats. Thus we dismissed it from our analysis.

We estimated diet richness as the overall number of items in the diet, and diet diversity, which indexes heterogeneity and accounts for relative abundance of each item in the diet (Krebs 1999). We estimated diet diversity using the Shannon-Wiener diversity index (H'), whereby the higher the index value, the more evenness in use across all resources:

$$
H^{\prime}=\sum \hat{\rho}_{i} \ln \hat{p}_{i}
$$

where $p_{i}$ is the total proportion of species $i$ in the sample (Colwell and Futuyma 1971). We estimated 95\% CI for diet richness, diversity, and volume of each of the nine major prey categories based on 1000 bootstrap re-samplings of scat data (Manly 2006). 
We used rarefaction to assess how diet diversity and richness varied with sample size (Krebs 1999). Rarefaction uses bootstrap resampling techniques to subsample from the initial dataset (without replacement) and estimate the mean and variance of the desired index (e.g., diversity, richness) for each sample size, $n$, from one to the maximum number of scat samples. We generated rarefaction curves based on 1000 bootstrap runs. Diet indices and bootstrapping and rarefaction analyses were calculated in Program R v 3.0.1 (R Development Core Team 2014).

\section{Results}

Scat collection

We collected 104 scat samples while tracking individual Wolverines from 10 March to 29 April $(n=83)$ and first visited GPS-identified clusters on 29 May ( $n$ $=22$; Figure 2 ). We followed $64 \mathrm{~km}$ of tracks, collecting 83 scats during 30 tracking events. We collected 21 scats from 20 GPS-cluster sites (14 snow-holes monitored by motion-activated cameras and six clusters detected by GPS collar locations). We also collected 29 scats from near a Moose carcass.

Faecal DNA analysis confirmed 70 of the 104 scats we collected as Wolverine, 23 as Red Fox (Vulpes vulpes), three as Arctic Fox (Vulpes lagopus), and eight with poor DNA quality that precluded identification. Of the 29 scats collected at the Moose carcass, 15 were identified as Wolverine, and we randomly chose one of these scats to include in our analysis (Marucco 2008; Bacon et al. 2011). We combined 15 of the scats collected at clusters identified as Wolverine into eight cluster scat samples, for a final sample size of 48 (40 from tracking and eight from GPS-clusters). Of the scats containing cricetids $(n=25)$, three contained Peary Land Collared Lemming (Dicrostonyx groenlandicus), two Brown Lemming (Lemmus trimucronatus), two Singing Vole (Microtus miurus), and others contained hairs that were non-cricetid or had poor quality DNA, preventing species identification. No soricids were found in scats.

\section{Scat analysis}

We classified prey remains and scat contents as one of 11 categories, five of which we identified to the species level (Figure 3): unknown ungulate (too degraded to distinguish between Moose or Caribou), Moose, Caribou, unknown carnivore (too degraded to determine species), fox, American Beaver, Snowshoe Hare, Arctic Ground Squirrel, cricetids, birds, and unknown (unidentified bone and other debris). We did not attempt to identify feather remains beyond the "bird" category because the majority of feathers were too highly degraded for species identification, although we expect that they were predominantly ptarmigan based on our

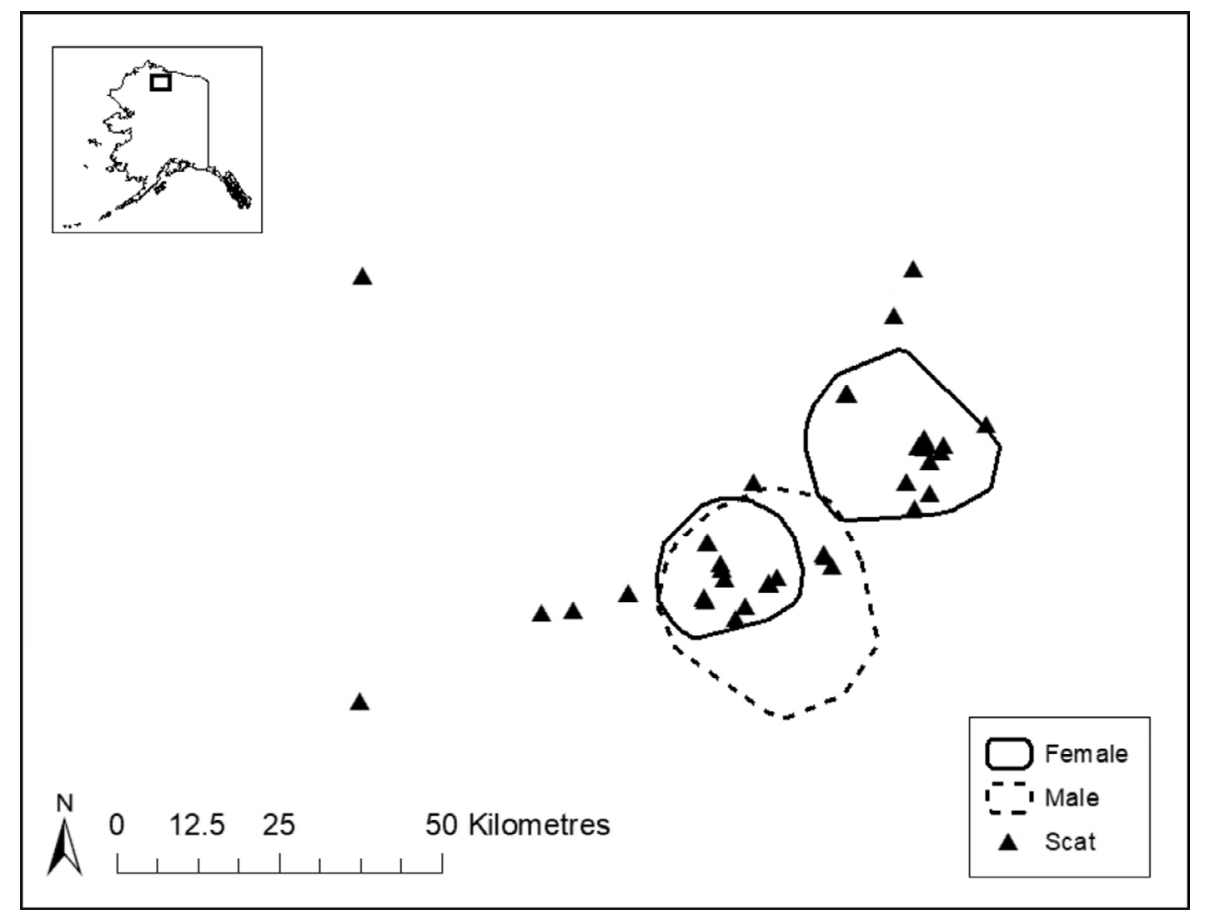

FiguRE 2. Locations of Wolverine (Gulo gulo) scats collected and home ranges of three Wolverines (one male, two female) near Umiat, Alaska, USA 10 March-29 April, and 29 May 2016. We collected 67 scats later confirmed through DNA analysis as Wolverine. Home ranges represent $95 \%$ minimum convex polygons. Locational details have been purposely omitted. 


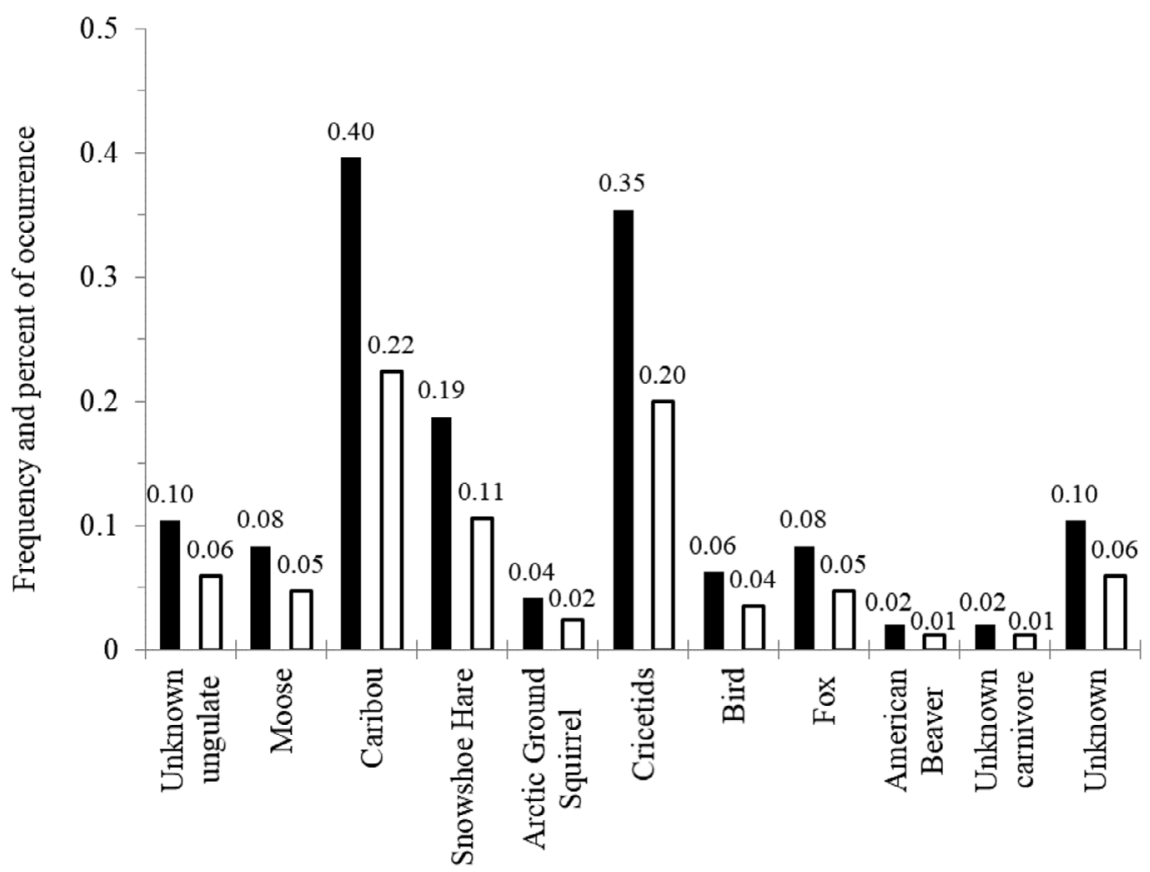

FIGURE 3. Frequency and percent of occurrence (FO and PO, respectively) of all prey species detected in combined Wolverine (Gulo gulo) scats $(n=48)$ collected near Umiat, Alaska, USA, 10 March-29 April, and 29 May 2016. Closed bars represent FO and open bars represent PO. Prey detected includes: unknown ungulate (Moose [Alces americanus], Caribou [Rangifer tarandus]), Moose, Caribou, Snowshoe Hare (Lepus americanus), Arctic Ground Squirrel (Urocitellus parryii), cricetids (Brown Lemming [Lemmus trimucronatus], Peary Land Collared Lemming [Dicrostonyx groenlandicus], Singing Vole [Microtus miurus]), bird (Aves), fox (Red Fox [Vulpes vulpes], Arctic Fox [Vulpes lagopus]), American Beaver (Castor canadensis), unknown carnivore (Carnivora), and unknown. Vegetation $(\mathrm{FO}=0.25, \mathrm{PO}=0.14)$ and woody debris $(\mathrm{FO}=0.06, \mathrm{PO}=0.04)$ not shown.

observations while in the area and consumption by Wolverines elsewhere.

Raw measures of FO and PO indicated that the four most commonly occurring items in scats were Caribou, cricetids, vegetation (assumed to be incidentally ingested during feeding or scat collection and not considered in further analyses), and Snowshoe Hare (Figure 3). Ranking prey items by volume indicated that the three most abundant identifiable items were Caribou, cricetids, and Snowshoe Hare. Cricetids and Caribou collectively represented $55 \%$ volume of the diet (Figure 3 ). Bootstrapped estimates of volume (mean $\pm \mathrm{SD}$ ) of each of the nine major prey categories indicated that ungulates $(0.49 \pm 0.07)$ and cricetids $(0.20 \pm 0.05)$ were the two primary prey resources (Figure 4). Arctic Ground Squirrel $(0.02 \pm 0.03)$ made a minor contribution to the diet.

Mean diet richness was eight resource categories ( $8.43 \pm 0.81$; Figure 5a). Mean Shannon-Wiener diversity index for scats was $1.75 \pm 0.11$. Rarefaction curves showed that mean diet richness continued to increase up to a sample size of about 40 scats, after which the rarefaction curve began to approach an asymptote (Figure $5 a)$. Rarefaction of mean diet diversity showed that the diversity curve approached an asymptote after a sample size of about 20 (Figure 5 b).

We observed five instances of active hunting by Wolverines between 13 and 22 May. Three events were of an adult male and two events of a single adult lactating female, exhibiting pouncing behaviour we attributed to hunting small mammals. We observed four out of five instances of hunting behaviour in tussock habitat.

\section{Discussion}

This study represents the second study of spring Wolverine diet north of the Brooks Range in Alaska (following Magoun 1987) and the first in the Colville River watershed. We documented a high prevalence of ungulates and cricetids in Wolverine scats, indicating the importance of these resources during spring. We also detected various predators (e.g., foxes), mid-size prey (Snowshoe Hare), and bird remains, documenting that Wolverines use a variety of prey types on the North Slope. Although we detected American Beaver in our scats, we attribute this to bait used by local trappers in the area as they are not a common species north of the Brooks Range of Alaska, although their range is increasing (MacDonald and Cook 2009; Tape et al. 2018). 


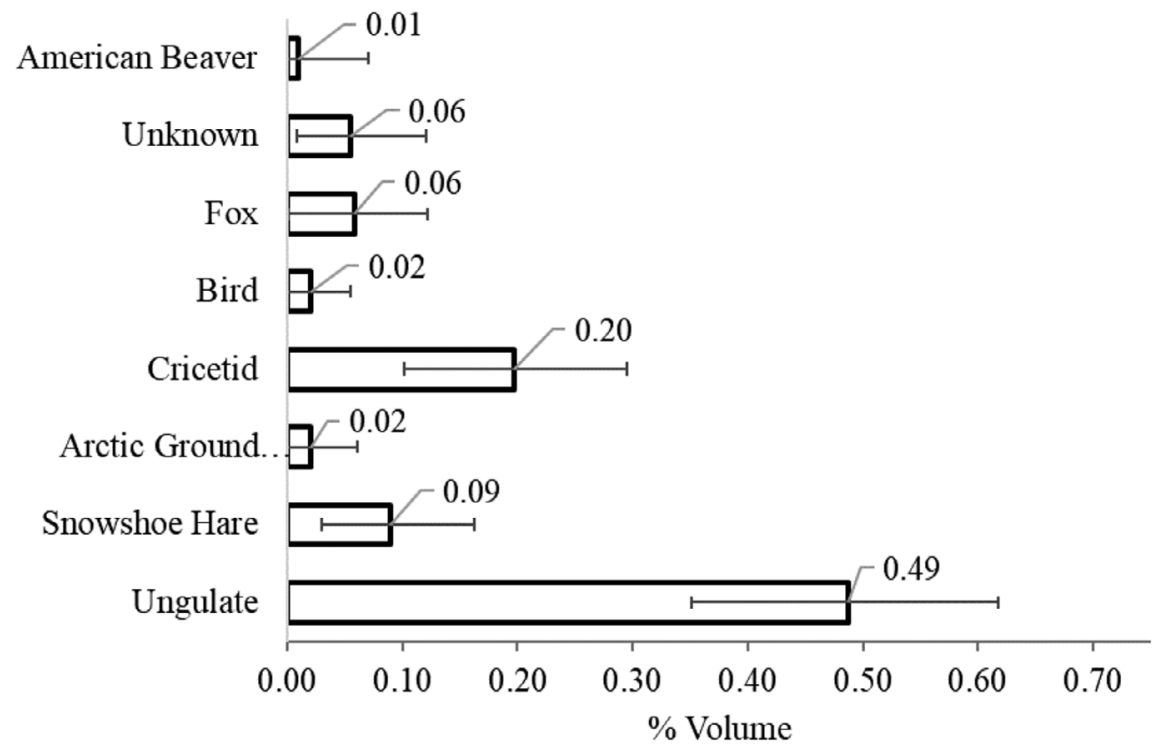

FigURE 4. Volume and $95 \%$ CI for each of eight prey categories detected in Wolverine (Gulo gulo) scats collected while tracking and from GPS clusters near Umiat, Alaska, USA,10 March-29 April, and 29 May 2016. We weighed the samples then conducted an ocular estimate of the percentage of each prey item in the scat to determine percent volume. We estimated CI from 1000 bootstrap re-samplings. Prey detected includes: ungulate (Moose, [Alces americanus], Caribou [Rangifer tarandus]), Snowshoe Hare (Lepus americanus), Arctic Ground Squirrel (Urocitellus parryii), cricetids (Brown Lemming [Lemmus trimucronatus], Peary Land Collared Lemming [Dicrostonyx groenlandicus], Singing Vole [Microtus miurus]), bird (Aves), fox (Red Fox [Vulpes vulpes], Arctic Fox [Vulpes lagopus]), Ermine (Mustela ermine), American Beaver (Castor canadensis). Other (7\%, including vegetation and woody debris) not shown.
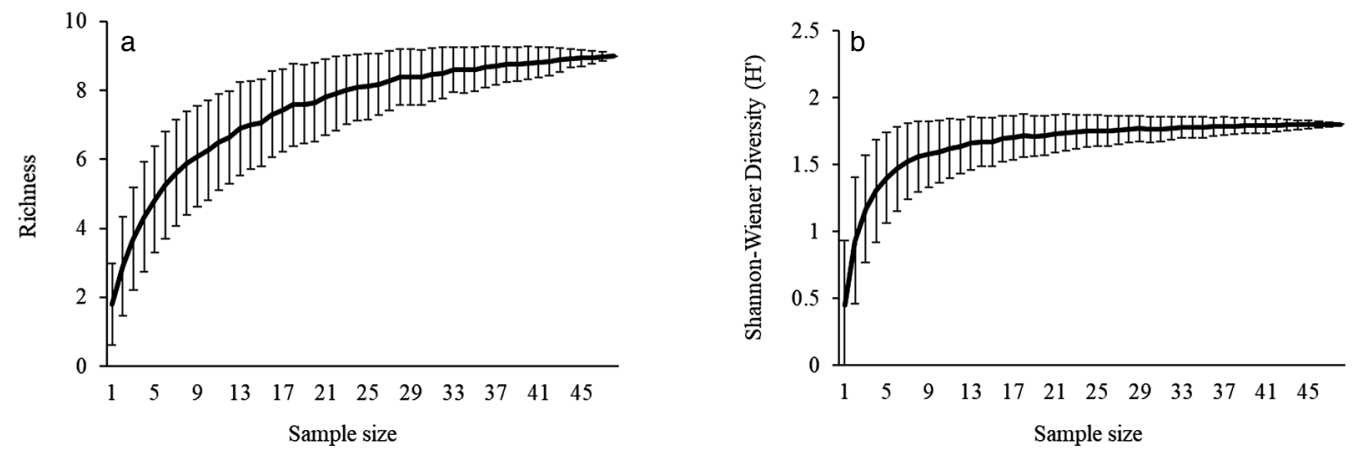

FIGURE 5. Rarefaction curves exhibiting the influence of sample size (x-axis) on Wolverine (Gulo gulo) diet richness (a) and diversity (b) estimated for scats collected near Umiat, Alaska, USA, 10 March-29 April, and 29 May 2016. Error bars show one SD estimated from 1000 bootstrap re-samplings of data.

Ungulates made up the largest portion of the Wolverines' diet based on our scat frequency and percentage of occurrence, and volume, which is similar to previous studies in North America and Fennoscandia (Lofroth et al. 2007; Dalerum et al. 2009; Koskela et al. 2013; Inman and Packila 2015). Moose contributed to diets of Wolverines in our study area, however due to their low abundance they likely are not a reliable prey source. The only Moose carcass we found provided an abundance of food for local Wolverines, but Caribou provide more overall biomass when available. Another Wolver- ine diet study in the southwestern Brooks Range (Dalerum et al. 2009), also found that Wolverines mainly subsisted on Caribou throughout the winter, despite the Western Arctic Caribou Herd's only seasonal availability (Lenart 2015). Dalerum et al. (2009) found that Caribou made up $>50 \%$ of stomach and colon contents in Wolverine carcasses. Because winter Caribou distribution on the North Slope is inconsistent between years (Dau 2015; Lenart 2015), access to Caribou in the winter can be supplemented from food caches. We were unable to determine whether prey remains were from cach- 
ing their own prey, scavenging other predator kills (such as from Gray Wolf [Canis lupus]), or from actively hunting. Obtaining this information would help reveal how Wolverines in our study area manage seasonally abundant ungulates compared to other prey sources (e.g., Arctic Ground Squirrel) that are less accessible in late winter. Similar to other studies basing diet inference on scats, only hair, bone, and feathers are available to determine FO and PO. This may underestimate a large prey item where large amounts of muscle are digested yielding a potentially smaller proportion of hair to biomass consumed. Other items, such as bird eggs may not be identified, but are known to be eaten by Wolverines (Magoun 1987; Samelius et al. 2002).

Although ungulates represent a significant portion of the Wolverines' diet in our and other studies (e.g., Mulders 2001; Dalerum et al. 2005, 2009; Lofroth et al. 2007; Inman and Packila 2015), cricetids are clearly another important prey. Cricetids composed the second highest frequency and percentage of occurrence, and volume for overall diet in our study. We also observed behaviour in spring consistent with hunting small prey, highlighting their potential significance as a spring food resource. Cricetid populations are irruptive and fluctuate over various temporal and spatial scales influencing their availability to Wolverines (Krebs and Myers 1974). The high proportion of cricetids detected in our Wolverine scats may reflect an abundance of cricetids throughout the study area. Wolverine scats could also contain a large proportion of cricetids because Wolverines preferentially selected them (Manly et al. 2002). Wolverines could increase their use of cricetids when snow begins to melt in the spring exposing subnivean prey at a time when the tundra tussock habitat is flooding with meltwater (as observed for the animals we saw hunting). However, without a measure of small mammal and ungulate abundance, it is unclear if Wolverines select for these prey resources on the North Slope, or adjust their intake based on availability alone during spring.

Cricetids, Snowshoe Hare, and Arctic Ground Squirrel collectively constitute $30 \%$ volume of spring Wolverine diet in our study. However, the role of small prey in Wolverine population dynamics is poorly understood and could be significant given the timing of availability relative to reproduction (Inman et al. 2012). Small mammal abundance in our area contributes to the diets of reproducing female Wolverines, when ungulates are only seasonally available, or as cached carrion. The availability and use of ungulates versus small mammals could influence Wolverine survival and reproductive success (Krebs et al. 2004; Persson 2005; Koskela 2013; Petersen 2014). Access to prey is particularly important when females are under increased energetic stress in late winter through summer while nursing and provisioning young with prey (Inman et al. 2012; Koskela 2013).
Future studies would benefit from determining diet composition of individual Wolverines to compare diet among home ranges. For example, a Wolverine that has an established territory in a riparian area may exclude another individual from access to a Moose carcass, thereby forcing the individual to find other prey sources. Our satellite collared Wolverines (R.D. unpubl. data), along with other radio tracking studies (Dawson et al. 2010; Persson et al. 2010), showed that Wolverines exhibit intrasexual territoriality, which likely precludes individuals of the same sex from accessing resources in neighbouring territories. Differences in diet among individual Wolverine territories could provide useful information on small-scale controls of population dynamics among habitat types, sex and age classes, and seasons.

Our work in the spring does not allow us to make inferences about summer diet. However, cricetids and Arctic Ground Squirrel may both be easier to hunt in summer months due to lack of snow cover and could be an important resource for Wolverine kits. In southern Norway, an abundance of cricetids in summer increased Wolverine kit survival (Landa et al. 1997). In addition, Arctic Ground Squirrel was an important diet resource for Wolverines on the western portion of the North Slope (Magoun 1987). Future studies would benefit from documenting summer Wolverine diets for kits and adults across a broader area, to determine the reliance on cricetids and Arctic Ground Squirrel, and their relation to Wolverine population dynamics.

Arctic Ground Squirrel represented only a small portion of the spring Wolverine diet in our study area, which differs from Magoun's (1987) findings, but may be confounded with the timing of our sampling. Near the Utukok River in the western portion of the North Slope, Wolverines fed on Caribou in mid-winter (December-February), but primarily fed on Arctic Ground Squirrel the rest of the year (Magoun 1987). Scats collected at the same time also contained large quantities of soil, likely from Wolverines digging up cached or hibernating Arctic Ground Squirrels (Magoun 1987). We observed negligible soil in the scats we sampled. However, the low frequency and percentage of occurrence and volume of Arctic Ground Squirrel in our analysis compared to Magoun (1987) could also relate to a difference in Arctic Ground Squirrel abundance and emergence dates between study areas. Our study area contains well drained soils preferred by Arctic Ground Squirrels, but their abundance is unknown (Barker and Derocher 2010). Assessing Arctic Ground Squirrel abundance and emergence throughout the area could aid interpretation of differences in the reliance on ground squirrels according to their activity and availability. This may be particularly important given the progressively earlier spring melt and potentially earlier availability of ground squirrels and cricetids through reduced snow pack (IPCC 2013). Furthermore, ground squirrels may increase in density in some well-drained 
areas as permafrost thaws in these northern ecosystems (Wheeler and Hik 2013).

To our knowledge, no other studies have used the Shannon-Wiener diversity index to calculate Wolverine diet diversity. We have no basis for comparing heterogeneity in resource use on the North Slope to other areas but monitoring how diet diversity changes over time or compares between areas could indicate differences in foraging strategies over time or among Wolverine populations. Future studies might consider adding this metric to their analysis to quantify how differences in resource use vary with the number of prey types in the diet. According to our rarefaction analysis, our sample size for diet richness may have been inadequate to provide accurate estimates of the average number of resources used by Wolverines. Future diet studies on the North Slope should consider increasing sample size to determine the full range of resources used by Wolverines.

A quantitative assessment of use versus availability would also provide improved insights into factors driving Wolverine prey selection, such as increased cricetid abundance, decreased ungulate abundance, or by the snowpack conditions affecting how cricetids and Arctic Ground Squirrels are accessible as the snowpack melts. Increased food availability corresponded with increased reproductive success of female Wolverines in Sweden (Persson 2005), thus, changes in food availability that influences reproductive success is a mechanism that could ultimately influence Wolverine abundance.

\section{Author Contributions}

Writing - Original Draft: R.D., K.S., and M.R.; Writing - Review \& Editing: R.D., K.S. M.R., T.G., and K.P.; Conceptualization: R.D., M.R., and K.S.; Investigation: R.D., T.G., K.S., and K.P.; Methodology: K.S., R.D., and T.G.; Formal Analysis: K.S. and K.P.; Funding Acquisition: M.R.

\section{Acknowledgements}

The M.J. Murdock Charitable Trust and Wilburforce Foundation provided funding. We thank Lincoln Parrett and Ryan Klimstra from the Alaska Department of Fish and Game, Knut Kielland, Brian Barnes, and Jeb Timm from the University of Alaska-Fairbanks, Richard Kemnitz from the Bureau of Land Management, Sally Andersen, Carrie Haddad, and Nicole Nufer from the Wildlife Conservation Society, and Audrey Magoun, Pat Valkenburg, Tina Laird, Mark Keech, and Bruce Stephenson for their support with logistics and intellectual input. We also thank Matthew Scrafford and Audrey Magoun for constructive reviews of earlier drafts of the manuscript.

\section{Literature Cited}

Bacon, M.M., G.M. Becic, M.T. Epp, and M.S. Boyce. 2011. Do GPS clusters really work? Carnivore diet from scat analysis and GPS telemetry methods. Wildlife Society Bulletin 35: 409-415. https://doi.org/10.1002/wsb.85

Banci, V. 1987. Ecology and behaviour of Wolverine in Yukon. M.Sc. thesis, Simon Fraser University, Burnaby, British Columbia, Canada. Accessed 22 April 2018. http:// summit.sfu.ca/system/files/iritems1/6062/b15354337.pdf.

Banci, V.A. 1994. Wolverine. Pages 99-127 in The Scientific Basis for Conserving Forest Carnivores: American Marten, Fisher, Lynx, and Wolverine in the Western United States. Edited by W.J. Ruggiero, F. Leonard, K.B. Aubry, S.W. Buskirk, L.J. Lyon, and W.J. Zielinski. U.S. Department of Agriculture, Forest Service, Rocky Mountain Forest and Range Experiment Station, Fort Collins, Colorado, USA. https://doi.org/10.5962/bhl.title.100456

Barker, O.E., and A.E. Derocher. 2010. Habitat selection by arctic ground squirrels (Spermophilus parryii). Journal of Mammalogy 91: 1251-1260. https://doi.org/10.1644/10MAMM-A-030.1

Batzli, G.O., and S.T. Sobaski. 1980. Distribution, abundance, and foraging patterns of ground squirrels near Atkasook, Alaska. Arctic and Alpine Research 12: 501-510. https://doi.org/10.2307/1550497

Carlee, E., and L. Horelick. 2011. Alaska fur ID project. Accessed 1 January 2016. https://alaskafurid.wordpress.com/ tips/.

Carroll, G. 2014. Moose management report, game management unit 26A. Species management report. Pages 35-135-22 in Moose Management Report of Survey-inventory Activities 1 July 2011-30 June 2013. Edited by P. Harper and L.A. McCarthy. Alaska Department of Fish and Game, Juneau, Alaska, USA. Accessed 1 January 2016. http:// www.adfg.alaska.gov/index.cfm?adfg=wildliferesearch. smr20146.

Churchill, E. 1955. Phytosociological and environmental characteristics of some plant communities in the Umiat region of Alaska. Ecology 36: 606-627. https://doi.org/10. 2307/1931299

Ciucci, P., L. Boitani, E. Pelliccioni, M. Rocco, and I. Guy. 1996. A comparison of scat-analysis methods to assess the diet of the wolf Canis lupus. Wildlife Biology 2: 37-48. Accessed 22 April 2018. http://www.airitilibrary.com/Publication/alDetailedMesh?docid=09096396-199603-2011 05050029-201105050029-37-48.

Colwell, R.K., and D.J. Futuyma. 1971. On the measurement of niche breadth and overlap. Ecology 52: 567-576. https://doi.org/10.2307/1934144

Dalerum, F., K. Kunkel, A. Angerbjörn, and B.S. Shults. 2009. Diet of wolverines (Gulo gulo) in the western Brooks Range, Alaska. Polar Research 28: 246-253. https://doi. org/10.1111/j.1751-8369.2008.00090.x

Dalerum, F., B. Shults, and K. Kunkel. 2005. A serologic survey for antibodies to three canine viruses in Wolverines (Gulo gulo) from the Brooks Range, Alaska. Journal of Wildlife Diseases 41: 792-795. https://doi.org/10.7589/00 90-3558-41.4.792

Dau, J. 2015. Units 21D, 22A, 22B, 22C, 22D, 22E, 23, 24 and 26A. Chapter 14. Pages 14-1-14-89 in Caribou Management Report of Survey and Inventory Activities 1 July 2012-30 June 2014. Edited by P. Harper and L.A. McCarthy. Alaska Department of Fish and Game, Juneau, Alaska, USA. Accessed 1 January 2016. http://www.adfg. alaska.gov/index.cfm?adfg=wildliferesearch.smr20154.

Dawson, F.N., A.J. Magoun, J. Bowman, and J.C. Ray. 2010. Wolverine, Gulo gulo, home range size and denning habitat in lowland boreal forest in Ontario. Canadian 
Field-Naturalist 124: 139-144. https://doi.org/10.22621/cfn. v124i2.1052

Dijk, V.J., L. Gustavsen, A. Mysterud, R. May, Ø. Flagstad, H. Broseth, and A. Landa. 2008. Diet shift of a facultative scavenger, the wolverine, following recolonization of wolves. Journal of Animal Ecology 77: 1183-1190. https:// doi.org/10.1111/j.1365-2656.2008.01445.x

Dijk, J.V., K. Hauge, A. Landa, R. Andersen, and R. May. 2007. Evaluating scat analysis methods to assess wolverine Gulo gulo diet. Wildlife Biology 13: 62-67. https://doi.org/ 10.2981/0909-6396(2007)13[62:ESAMTA]2.0.CO;2

Fancy, S.G., L.F. Pank, K.R. Whitten, and W.L. Regelin. 1989. Seasonal movements of caribou in arctic Alaska as determined by satellite. Canadian Journal of Zoology 67: 644-650. https://doi.org/10.1139/z89-093

Inman, R.M., A.J. Magoun, J. Persson, and J. Mattisson. 2012. The wolverine's niche: linking reproductive chronology, caching, competition, and climate. Journal of Mammalogy 93: 634-644. https://doi.org/10.1644/11-MAMM $-A-319.1$

Inman, R.M., and M.L. Packila. 2015. Wolverine (Gulo gulo) food habits in greater Yellowstone. American Midland Naturalist 173: 156-161. https://doi.org/10.1674/0003-0 031-173.1.156

IPCC (Intergovernmental Panel on Climate Change). 2013. Climate change 2013: the physical science basis. contribution of working group I to the fifth assessment report of the intergovernmental panel on climate change. Edited by T.F. Stocker, D. Qin, G.-K. Plattner, M. Tignor, S.K. Allen, J. Boschung, A. Nauels, Y. Xia, V. Bex, and P.M. Midgley. Cambridge University Press, Cambridge, United Kingdom and New York, New York, USA. https://doi.org/10.1017/ CBO9781107415324

Klare, U., J.F. Kamler, and D.W. MacDonald. 2011. A comparison and critique of different scat-analysis methods for determining carnivore diet. Mammal Review 41: 294-312. https://doi.org/10.1111/j.1365-2907.2011.00183.x

Koskela, A., L. Kojola, J. Aspi, and M. Hyvärinen. 2013. Effect of reproductive status on the diet composition of wolverines (Gulo gulo) in boreal forests of eastern Finland. Annales Zoologici Fennici 50: 100-106. https://doi.org/10. 5735/086.050.0109

Krebs, C.J. 1999. Ecological Methodology. Second Edition. Benjamin Cummings, Berkeley, California, USA.

Krebs, C.J., E. Lofroth, J. Copeland, V. Banci, D. Cooley, H. Golden, and B. Shults. 2004. Synthesis of survival rates and causes of mortality in North American Wolverines. Journal of Wildlife Management 68: 493-502. https://doi.org/1 0.2193/0022-541X(2004)068[0493:SOSRAC]2.0.CO;2

Krebs, C.J., and H. Myers. 1974. Population cycles in small mammals. Advances in Ecological Research 8: 267-273. https://doi.org/10.1016/S0065-2504(08)60280-9

Landa A., O. Strand, J.E. Swenson, and T. Skogland. 1997. Wolverines and their prey in southern Norway. Canadian Journal of Zoology 75: 1292-1299. https://doi.org/10.1139/ z97-153

Lenart, E.A. 2015. Units 26B and 26C caribou. Chapter 18. Pages 18-1-18-38 in Caribou Management Report of Survey and Inventory Activities 1 July 2012-30 June 2014. Edited by P. Harper and L.A. McCarthy. Alaska Department of Fish and Game, Juneau, Alaska, USA. Accessed 3 January 2016. http://www.adfg.alaska.gov/index.cfm?adfg=wild liferesearch.smr20154.

Lofroth, E.C., J.A. Krebs, W.L. Harrower, and D. Lewis. 2007. Food habits of wolverine Gulo gulo in montane eco- systems of British Columbia, Canada. Wildlife Biology 13: 31-37. https://doi.org/10.2981/0909-6396(2007)13[31:FH OWGG]2.0.CO;2

MacDonald, S.O., and J.A. Cook. 2009. Recent Mammals of Alaska. University of Alaska Press, Fairbanks, Alaska, USA.

Magoun, A.J. 1987. Summer and winter diets of Wolverines, Gulo gulo, in arctic Alaska. Canadian Field-Naturalist 101: 392-397. Accessed 7 February 2019. https://biodiversity library.org/page/28089821.

Manly, B.F. 2006. Randomization, Bootstrap and Monte Carlo Methods in Biology. Third Edition. CRC Press, Boca Raton, Florida, USA.

Manly, B.F., L.L. McDonald, D.L. Thomas, T.L. McDonald, and W.P. Erickson. 2002. Introduction to Resource Selection Studies. Pages 1-15 in Resource Selection by Animals. Second Edition. Springer Netherlands, Dordrecht, Netherlands. https://doi.org/10.1007/0-306-48151-0_1

Marucco, F., S.H. Pletscher, and L. Boitani. 2008. Accuracy of scat sampling for carnivore diet analysis: wolves in the alps as a case study. Journal of Mammalogy 89: 665-673. https://doi.org/10.1644/07-MAMM-A-005R3.1

Mattisson J., G.R. Rauset, J. Odden, H. Andrén, J.D.C. Linnell, and J. Persson. 2016. Predation or scavenging? Prey body condition influences decision-making in a facultative predator, the wolverine. Ecosphere 98: 40-46. https:// doi.org/10.1002/ecs2.1407

Moore, T., L. Spence, and C. Dugnolle. 1974. Identification of the dorsal guard hairs of some mammals of Wyoming. Edited by W.G. Hepworth. Wyoming Game and Fish Department, Cheyenne, Wyoming, USA.

Mulders, R. 2001. Wolverine ecology, distribution, and productivity in the Slave Geological Province. Department of Resources, Wildlife and Economic Development, Yellowknife, Northwest Territories, Canada. Accessed 1 January 2016. http://www.enr.gov.nt.ca/sites/enr/files/wkss_wolv erine_ecology_final_report_2001.pdf.

NOAA (National Oceanic and Atmospheric Administration and National Centers for Environmental Information). 2018. Daily summaries station details. Accessed 22 April 2018. https://tinyurl.com/ybm2pemb.

Persson, J. 2005. Female Wolverine (Gulo gulo) reproduction: reproductive costs and winter food availability. Canadian Journal of Zoology 83: 1453-1459. https://doi.org/10.1139/ z05-143

Persson, J., P. Wedholm, and P. Segerström. 2010. Space use and territoriality of Wolverines (Gulo gulo) in northern Scandinavia. European Journal of Wildlife Research 56: 49-57. https://doi.org/10.1007/s10344-009-0290-3

Petersen, I.S. 2014. Juvenile and subadult survival in Scandinavian wolverines (Gulo gulo) in relation to sex and small rodent abundance. M.Sc. thesis, Norwegian University of Life Sciences, Ås, Norway. Accessed 3 January 2016. https://hdl.handle.net/11250/217948.

R Development Core Team. 2014. R: A language and environment for statistical computing. R Foundation for Statistical Computing. Vienna, Austria.

Samelius, G., R.T. Alisauskas, S. Larivière, C. Bergman, C.J. Henderickson, K. Phipps, and C. Wood. 2002. Foraging behaviours of Wolverines at a large arctic goose colony. Arctic 55: 148-150. https://doi.org/10.14430/arctic699

Schwartz, M.K., K.B. Aubry, K.S. McKelvey, K.L. Pilgrim, J.P. Copeland, J.R. Squires, R.M. Inman, S.M. Wisely, and L.F. Ruggiero. 2007. Inferring geographic isolation of Wolverines in California using historical DNA. Journal 
of Wildlife Management 71: 2170-2179. https://doi.org /10.2193/2007-026

Shardlow, T.F. 2013. Isotopic evidence of salmon, Oncorhynchus spp., in the diet of the Wolverine, Gulo gulo, on Princess Royal Island, British Columbia. Canadian Field-Naturalist 127: 338-342. https://doi.org/10.22621/cfn.v127i4. 1515

Tape, K.D., D.D. Gustine, R.W. Ruess, L.G. Adams, and J.A. Clark. 2016. Range expansion of moose in aretic Alaska linked to warming and increased shrub habitat. PLoS ONE 11: e0160049. https://doi.org/10.1371/journal.pone. 0152636

Tape, K.D., B.M. Jones, C.D. Arp, I. Nitze, and G. Grosse. 2018. Tundra be dammed: beaver colonization of the arctic.
Global Change Biology 24: 4478-4488. https://doi.org/ $10.1111 / \mathrm{gcb} .14332$

Viereck, L.A., C.T. Dyrness, A.R. Batten, and K.J. Wenzlick. 1992. The Alaska vegetation classification. General Technical Report. U.S. Department of Agriculture, Forest Service, Pacific Northwest Research Station. Portland, Oregon, USA. https://doi.org/10.3996/112015-JFWM-116.S7

Wheeler, H.C., and D.S. Hik. 2013. Arctic ground squirrels Urocitellus parryii as drivers and indicators of change in northern ecosystems. Mammal Review 43: 238-255. https: //doi.org/10.1111/j.1365-2907.2012.00220.x

Received 22 April 2017

Accepted 1 August 2018 